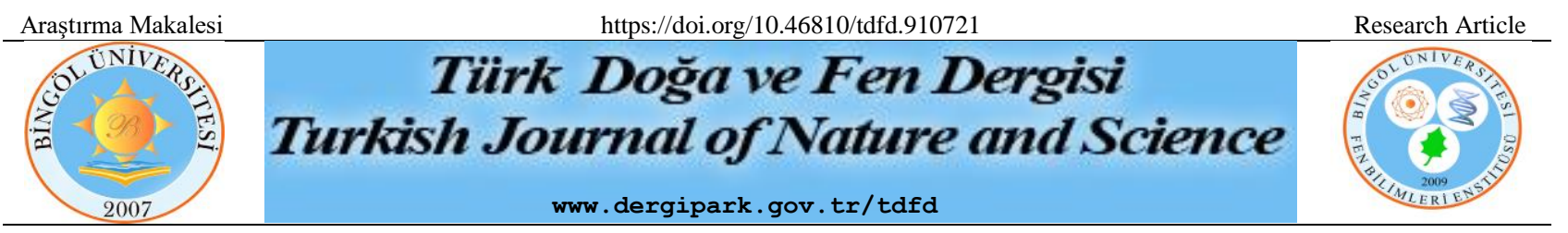

\title{
Demir Noksanlığı Şartlarında Fasulye Çeşitlerinin Demir Beslenme Kabiliyetlerine Göre Gruplandırılması ve Çeşitlerin En İyi Demir Beslenme İndekslerinin Belirlenmesi
}

\author{
Ahmet KORKMAZ ${ }^{*}$, Ilkay ÇOKA ${ }^{2}$, Güney AKINOĞLU ${ }^{1}$ \\ ${ }^{1}$ Ondokuz Mayıs Üniversitesi, Ziraat Fakültesi, Toprak Bilimi ve Bitki Besleme Bölümü, Samsun, Türkiye \\ ${ }^{2}$ Mersin Üniversitesi, Mustafa Baysan Meslek Yüksekokulu, Bitkisel ve Hayvansal Üretim Bölümü, Mersin, Türkiye \\ Ahmet KORKMAZ ORCID No: 0000-0001-5595-0618 \\ İlkay ÇOKA ORCID No: 0000-0001-8387-8457 \\ Güney AKINOĞLU ORCID No: 0000-0003-4624-2876 \\ *Sorumlu yazar: guney_akinoglu@ymail.com
}

(Alınış: 06.04.2021, Kabul: 25.05.2021, Online Yayınlanma: 31.12.2021)

\begin{abstract}
Anahtar
Kelimeler

Fasulye

çeşitleri,

Aktif demir,

Demir

noksanlığına

dayanıklılık,

Ferrik

redüktaz

aktivitesi,

Klorofil

Öz: $\mathrm{Bu}$ çalışmanın amacı, demir noksanlığı şartlarında fasulye çeşitlerinin demir beslenme kabiliyetlerine göre gruplandırılması ve çeşitlerin en iyi demir beslenme indekslerinin belirlenmesidir. Çalışmada 15 fasulye çeşidi karşılaştırılmıştır. Fasulye çeşitlerine Fe-EDDHA formunda; a) Yetersiz $(0,2 \mu \mathrm{M} \mathrm{Fe})$, b) Yeterli $(45 \mu \mathrm{M}$ ve $100 \mu \mathrm{M}$ Fe) konsantrasyonlarda demir içeren besin çözeltisi verilmiştir. $15 \times 3$ faktöriyel denemede muameleler 3 tekerrürlü uygulanmıştır. Demir beslenmeleri yönünden çeşitlerin karşılaştırılmasında bitki kuru madde miktarı, yaprakta klorofil, aktif demir kapsamları, ferrik redüktaz aktivitesi ve diğer bazı özellikler kullanılmıştır. Demir noksanlığı şartlarında demir beslenme özellikleri yönünden çeşitler 3 grup oluşturmuştur. 10 numaralı çeşit birinci grupta; 1, 5, 2, 11, 6, 3, 9 numaralı çeşitler ikinci grupta; 4, 12, 15, 13, 14, 7, 8 numaralı çeşitler ise üçüncü grupta yer almışlardır. Demir noksanlığ 1 şartlarında Önceler (1 nolu çeşit) ve Eskfbud-7 (10 nolu çeşit), birbirinden en uzak çeşitlerdir. Önceler ve Eskfbud-7 çeşitlerinde demir noksanlığına tolerans indeks değerleri yeterli seviyeye göre (45 $\mu \mathrm{M} \mathrm{Fe}$ ) klorofil-a yönünden çeşit sırasıyla \% 27,93 ve \% 74,39; klorofil-b yönünden \% 37,60 ve \% 119,4; toplam klorofil yönünden \% 131,31 ve \% 97,2 bulunmuştur. Eskfbud-7 bodur fasulye çeşidinin demir noksanlığına daha dayanıklı bir çeşit olduğu sonucuna varılmıştır.
\end{abstract}

\section{Determination of the Best Iron Nutrition Indexes of Bean Cultivars in Iron Deficiency Conditions and Grouping of Varieties According to These İndexes}

Keywords

Bean varieties,

Active iron,

Resistance to

iron

deficiency,

Ferric

reductase

activity,

Chlorophyll

\begin{abstract}
The aim of this study is to group bean varieties according to their iron nutritional abilities under iron deficiency conditions and to determine the best iron nutritional index of the varieties. 15 bean varieties were compared in the study. Bean varieties in the form of $\mathrm{Fe}$ EDDHA; a) Insufficient ( $0.2 \mu \mathrm{M} \mathrm{Fe})$, b) Sufficient ( $45 \mu \mathrm{M}$ and $100 \mu \mathrm{M} \mathrm{Fe})$ iron-containing nutrient solution was given. In the $15 \times 3$ factorial trial, the treatments were applied in 3 replications. In the comparison of the varieties in terms of iron nutrition, the amount of plant dry matter, chlorophyll in the leaf, active iron content, ferric reductase activity and some other properties were used. The varieties formed 3 groups in terms of iron nutritional properties under iron deficiency conditions. Number 10 is in the first group; Varieties with numbers $1,5,2,11$, $6,3,9$ are in the second group; Varieties with numbers 4, 12, 15, 13, 14, 7, and 8 were in the third group. In iron deficiency conditions, Önceler (variety number 1) and Eskfbud-7 (variety number 10) bean varieties are the farthest from each other. The tolerance index values for iron deficiency in Önceler and Eskfbud-7 varieties were found to be $27,93 \%$ and $74,39 \%$, respectively for chlorophyll-a; 37,60\% and 119,4\% for chlorophyll-b; $131,31 \%$ and $97,2 \%$ for total chlorophyll according to the sufficient level $(45 \mu \mathrm{M} \mathrm{Fe})$. It was concluded that Eskfbud-7 bean variety is more resistant to iron deficiency.
\end{abstract}




\section{GíRiş}

Demir noksanlığı, bitkisel üretimde önemli mikro element noksanlık problemidir. Demir noksanlığının düzeltilmesi masraflı bir yoldur. Diğer taraftan demir eksikliği özellikle gelişmekte olan ülkelerde hayvan ve insan sağlığında önemli bir beslenme sorunu oluşturmaktadır. İnsanlarda demir noksanlığının yaygın bir şekilde görülmesinin başlıca sebeplerinden biri demir kapsamı düşük bitkisel gıdaların tüketimine atfedilmektedir. Bitkilerde demir noksanlığının nedeni toprakta mutlak eksikliğe ilave olarak demir çözünürlüğünü azaltan bazı toprak özellikleridir. Ayrıca, demir noksanlığının nedenleri arasında bitki köklerinin genetik olarak demir alımında etkin bir özelliğe sahip olmamasidir.

Baklagil bitkilerinde demir, hem konukçu hem de kök nodül bakterilerin gelişmesi için temel bir besin elementidir. Demir konukçu bitkide fotosentezde, solunumda, klorofil oluşumunda, karotenoid sentezinde, DNA sentezinde, protein sentezinde ve nitrat azotunun amonyağa indirgenmesinde büyük bir öneme sahiptir [1].

Baklagil bitkilerinde demir azot fiksasyonunda esansiyel bir elementtir. Baklagil Rhizobia simbiyosisi özellikle demir noksanlığına hassastır. Baklagillerde nodüllerle azot fiksasyonu ve bitkinin demir noksanlığ d durumunda gösterdiği respons $\mathrm{H}^{+}$üreten sistemler olup bu fizyolojik olaylarının biri diğerinin aktivitesini interaksiyon şeklinde etkileyebileceği bildirilmiştir [1].

Demir baklagil yetiştirme ortamında bakterilerin sayısı, çoğalması, nodül oluşumu, nodül miktarı, nodül sayısı, nitrojenaz aktivitesini etkileyen öncelikli bir elementtir. Demir nodül içerisinde leghemoglobin oluşumunu ve nitrojenaz aktivitesini etkilemesi sebebiyle kritik öneme sahiptir [2]. Nodül içerisinde leghemoglobin oluşumu nodüllerin azot fiksasyonunda etkin olabilmesi için gereklidir. Ayrica, leghemoglobin maddesi nitrojenazı oksijenin zararlı etkisinden korur. Bununla birlikte, nitrojenaz enziminde demir ve molibden vardır. Genel olarak biyolojik azot fiksasyonunda ihtiyaç duyulan maddeler şunlardır: 1- Nitrojenaz enziminin üretimi: Bakteri tarafından üretilen bu enzim demir ve molibden beslenmesinin iyi olmasını gerektirir. 2-Adenozin trifosfat: Bakteri tarafından solunumla sağlanır. 3Nitrojenazı oksijenden koruyucu sistem: Leghemoglobin maddesinin yapılmasını gerektirir. Bu maddenin üretimi için demir beslenmesi iyi olmalıdır. Leghemoglobin oksijen difüzyonunu regüle eder. $4-\mathrm{H}^{+}$iyonu gereklidir. Hidrojen iyonu bakteri tarafından solunumla sağlanır. 5Oluşan amonyağın aminoasit oluşumunda kullanılması gereklidir [3].

O’Hara ve ark. [4], yeterli miktarda demirin baklada nodüllerin oluşumu için ve yerfistığında nodüllerin gelişmesi için esansiyel bir element olduğunu belirtmişlerdir. Araştırıcılar yaptıkları çalışmada alkalin besin çözeltisinde demir stresi şartlarında yetiştirilen yer fistığında Bradyrhizobium ırklarının bitkide nodül oluşturma etkinliklerinin farklı olduğu tespit etmişlerdir.
Demir alımında etkin fasulye çeșitlerinin seçiminde indeks değerler olarak demirce noksan ve yeterli ortamda yetiştirilen çeşitlerde yaprakların klorofil kapsamları, kloroz indeks değerleri, yaprakta aktif demir, kök ve yaprakta ferrik-redüktaz enzim aktivitesi, kök ortamında asitlik oluşturma kapasitesi dikkate alınmaktadır. Son çalışmalarda fasulye Rhizobium simbiyosusunda demirin önemi nedeniyle farklı fasulye çeşitlerinin köklerinde oluşan nodüllerde demir kapsamı da indeks olarak kullanılmıștır [5].

Ülkemizde demir eksikliği problemine genellikle $\mathrm{pH}$ değerleri yüksek olan kireçli topraklarda rastlanmaktadır. Eyüpoğlu ve Kurucu [6], yapmış oldukları bir araştırmada Türkiye tarım topraklarının \% 27'sinde demir eksikliği görüldüğünü bildirmişlerdir. Topraklardaki yüksek pH ve kireçle beraber, bitkilerde demir klorozunun ortaya çıktığı ve Türkiye topraklarının büyük bir çoğunluğunun alkali reaksiyonlu topraklardan oluştuğu dikkate alınırsa demir noksanlığı sorununun büyüklüğü kolayca anlaşılabilir.

Özgümüş [7], demir noksanlığının önlenmesinde alınacak tedbirlerin önem sırasına göre aşağıdaki gibi olması gerektiği bildirmiştir: I-) Genetik kontrol, II-) Demir noksanlığına sebep olan toprak özelliklerinin iyileştirilmesi, III-) Demirli gübrelemedir. Genetik kontrol önlemlerin en önemlisidir. Demir noksanlığına sebep olan toprak özelliklerinin iyileştirilmesi ve demirli gübreleme çiftçiye ek masraflar getirir. Diğer yandan, demir noksanlık riski yüksek arazilerde bitkilerde demir noksanlığının görülmemesi için yapılabilecek en doğru ve kalıcı bir yaklaşım toprakta var olan demiri etkin bir şekilde kullanabilen genotiplerin seçilmesi ve böylece bu genotiplerin 1slah çalışmalarında demir eksikliğine toleransı yüksek yeni çeşitlerin geliştirilmesinde kullanılması olacaktır. Bu nedenle, demir noksanlık riski yüksek arazilerde demir klorozuna toleranslı genotipler toprakta alınamaz durumdaki demiri alınabilir forma geçiren bazı fizyolojik ve morfolojik adaptasyon mekanizmaları geliştirmişlerdir. $\mathrm{Bu}$ mekanizmalar neticesinde bu genotiplerin kökleri ile yeterli miktarda demir aldıkları belirtilmiştir. Demir noksanlık şartlarına adaptasyonda köklerin verdiği cevaplar bitki türleri arasında farklılık göstermektedir. Fasulye dahil Strateji-I bitkisi olarak adlandırılan bitkiler köklerinde morfolojik ve fizyolojik bazı değişiklikler oluşturarak demir noksanlığına adapte olmaya çalışırlar $[8,9,10,11]$. Demir alımında kök yüzeylerinde $\mathrm{Fe}^{+3}$ ün $\mathrm{Fe}^{+2}$ ye indirgenmesi mutlak gerekli bir işlem olduğu belirtilmiştir [12, 13]. Marschner ve ark. [14] demir noksanlığı şartlarında Strateji-I bitkilerinin diğer bir özelliğinin $\mathrm{ATP}_{\mathrm{az}}$ proton pompasıly rizosferin asitliğini arttırma olduğu ve bu özelliğin rizosferde demirin çözünürlügünü arttırarak, bitkinin demir beslenmesine katkı sağladığını bildirmiş̧lerdir.

$\mathrm{Bu}$ çalışmanın amacı, demir noksanlığı şartlarında fasulye çeşitlerinin demir beslenme kabiliyetlerine göre gruplandırılması ve çeşitlerin en iyi demir beslenme indekslerinin belirlenmesidir. 


\section{MATERYAL VE METOT}

Çalışmada incelenen 15 farklı fasulye çeşidi T.C. Tarım ve Orman Bakanlığı Karadeniz Tarımsal Araştırma Enstitüsü Müdürlügü̈'nden temin edilmiştir. Çalışmada incelenen 15 farklı fasulye çeşidinin isimleri aşağıda belirtilmiştir:

1-Önceler (Sırık), 2-Göynük (Bodur), 3-Eskfbud-2 (Surkk), 4- Ktakfbv.2(FÇ.113) (Bodur), 5 Safhat (Eskfbvd-6) (Bodur), 6 Yunus90 ( bodur), 7-Eskfbud-11 (Sırı), 8-Eskfbvd-14 (Safhat) (Sirı), 9Zülbiye(Bodur), 10-Eskfbud-7(Bodur), 11-Karalcaşehir 90 (Bodur), 12-Ada - 13-6-(Bodur), 13-Ktakfbvd1(safhat) (Bodur), 14- Ktakfbvd-3(Fç.304) (Bodur), 15Eskfbvd-8-(safhat) (Bodur).

Denemede içeriği Hewitt [15] tarafından bildirilen ve pH'sı 6,0'a ayarlı aşağıdaki besin çözeltisi uygulanmıştır:

$1,0 \mathrm{mM} \mathrm{NH}_{4} \mathrm{NO}_{3} ; 1,60 \mathrm{mM} \mathrm{KH}_{2} \mathrm{PO}_{2} ; 3,50 \mathrm{mM} \mathrm{CaSO}_{4}$;

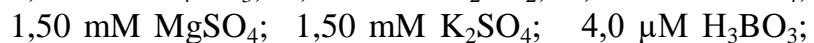
$4,0 \mu \mathrm{M} \quad \mathrm{ZnSO}_{4} ; \quad 4,0 \mu \mathrm{M} \quad \mathrm{MnSO}_{4} ; \quad 0,12 \mu \mathrm{M}$ $\left(\mathrm{NH}_{4}\right)_{6} \mathrm{Mo}_{7} \mathrm{O}_{24}$

445 g kuvars kumu dolu saksılarda $15 \times 3$ (çeşit $\times$ demir dozu) şeklinde tesadüf parselleri deney deseninde faktöriyel deneme 3 tekerrürlü olarak yürütülmüsstür. FeEDDHA formunda demir dozları, noksan $(0,2 \mu \mathrm{M} \mathrm{Fe})$, yeterli $(45 \mu \mathrm{M} \mathrm{Fe})$, yeterli $(100 \mu \mathrm{M}$ Fe $)$ şeklinde uygulanmıştır.

Her saksıda bir fasulye bitkisi kalacak şekilde seyreltme yapılmıştır. Her saksıya makro ve mikro besin maddesi içeren besin çözeltisinden her gün 50'şer $\mathrm{mL}$; yukarıdaki belirtilen konsantrasyonlarda hazırlanmış Fe-EDDHA çözeltisinde ise her doz için 30 'ar $\mathrm{mL}$ uygulanmıştır. Fasulye çeşitleri 50 gün süreyle yetiştirilmiştir. Taze yaprakta yapılacak analizler için yaprak örneği alınmıştır. Bitkilerin toprak-üstü aksamları $65{ }^{\circ} \mathrm{C}$ 'ye ayarlı etüvde kurutularak, kuru madde ağırlıkları belirlenmiştir [16].

Taze yapraklarda ferrik redüktaz aktivitesi Ojeda ve ark. [17] tarafından bildirilen metoda göre yapılmıştır.

Taze yaprak örneklerinde aktif demir belirlenmiştir. Bunun için taze yaprak örneği 1,0 N hidroklorik asit ile ekstrakte edilmis, süzükte aktif demir atomik absorpsiyon spektrofotometre ile belirlenmiştir [18].

Taze yaprak örneklerinde Arnon [19]; Witham ve ark. [20] tarafindan bildirildiği şekilde klorofil-a, klorofil-b ve toplam klorofil tayini yapılmıştır.

Kacar ve İnal [16], tarafindan bildirildiği gibi bitkide toplam azot, fosfor, potasyum ve demir belirlenmiştir. Ayrıca bitkilerin ortamdan kaldırdıkları toplam demir alımları hesap edilmiștir. Fasulye çeşitlerinde demir noksanlı̆̆ şartlarında oransal klorofil-a, klorofil-b, toplam klorofil, kuru madde ve aktif demir değerleri yüzde olarak aşağıdaki gibi hesaplanmıştır:

Oransal değerler, $\%=(\mathrm{A} / \mathrm{B}) \times 100$

Burada;

A: Demir noksanlığı şartlarında fasulye çeşitlerinde belirlenen klorofil-a, klorofil-b, toplam klorofil, kuru madde ve aktif demir kapsamları

B: $45 \mu \mathrm{M}$ ya da $100 \mu \mathrm{M}$ demir uygulaması şartlarında fasulye çeşitlerinde belirlenen klorofil-a, klorofil-b, toplam klorofil, kuru madde ve aktif demir kapsamları

Demir noksanlığg şartlarında demir beslenme indeksleri yönünden fasulye çeşitlerinin birbirlerine yakınlık ve uzaklıklarını belirlemek amacıyla Cluster (kümeleme) testi veya benzerlik testi uygulanmıştır. Cluster analizi JMP.5.0 istatistik paket programında Ward Yöntemi'ne göre yapılmıștır. Ayrıca demir beslenme indekslerinin ve diğer özelliklerin çeşitlere göre sinıflandırılması ve çeşitlerin bu indeks ve özelliklere göre değişimi ve çeşitlerin en iyi özelliklerini belirlemek amacıyla Biplot analizi yapılmıștır.

\section{BULGULAR}

\subsection{Demir Noksanlı̆̆ Sartlarında Fasulye Çeşitlerinin Gruplandırılması, Yakınlık-Uzaklıkları ve En İyi Özellikleri}

Demir noksanlığ şartlarında yetiștirilen fasulye çeşitlerinde belirlenen demir beslenme özelliklerine ilişkin değerler Tablo 1'de verilmiştir. Ayrıca, demir noksanlı ̆ı şartlarında fasulye çeșitlerinde hesaplanan bu özelliklere ilişkin oransal değerler Tablo 2 ve Tablo 3'te verilmiştir.

Tablo 1. Demir noksanlığı şartlarında yetiștirilen fasulye çeșitlerinin demir beslenme durumlarını gösteren bazı özellikleri

\begin{tabular}{|c|c|c|c|c|c|c|c|c|c|c|c|}
\hline $\begin{array}{l}\text { Fasulye } \\
\text { çeşit no }\end{array}$ & $\begin{array}{c}\text { Kuru } \\
\text { madde, } \\
\text { gKM/bitki }\end{array}$ & $\begin{array}{c}\text { Klorofil } \\
\text { a,mg/gTM }\end{array}$ & $\begin{array}{c}\text { Klorofil } \\
\text { b,mg/gTM }\end{array}$ & $\begin{array}{l}\text { Toplam } \\
\text { klorofil, } \\
\text { mg/gTM }\end{array}$ & $\begin{array}{c}\text { Aktif } \\
\text { Fe, } \\
\text { ppm }\end{array}$ & $\begin{array}{c}\text { Yaprakta } \\
\text { FRA, } \\
\mu \mathrm{mol} / \mathrm{saat} / \mathrm{g} \\
\text { TM }\end{array}$ & $\begin{array}{c}\text { Kök KDK, } \\
\text { me/100gKM }\end{array}$ & $\begin{array}{c}\text { Bitkide } \\
\text { toplam } \\
\text { N, \% }\end{array}$ & $\begin{array}{c}\text { Bitkide } \\
\text { toplam } \\
\text { P, \% }\end{array}$ & $\begin{array}{c}\text { Bitkide } \\
\text { toplam } \\
\text { K, \% }\end{array}$ & $\begin{array}{c}\text { Toplam } \\
\text { demir } \\
\text { kapsamı, } \\
\text { ppm }\end{array}$ \\
\hline 1 & 7,09 & 0,25 & 0,18 & 0,43 & 20,73 & 27,94 & 7,84 & 2,4 & 0,69 & 2,32 & 158 \\
\hline 2 & 6,1 & 0,33 & 0,23 & 0,55 & 14,27 & 3,66 & 7,88 & 2,35 & 0,67 & 2,86 & 139 \\
\hline 3 & 6,43 & 0,46 & 0,3 & 0,76 & 17,56 & 27,7 & 6,01 & 2,82 & 0,78 & 2,72 & 212 \\
\hline 4 & 10,7 & 0,36 & 0,19 & 0,54 & 17,53 & 41,74 & 6,02 & 2,25 & 0,65 & 2,07 & 144 \\
\hline 5 & 9,02 & 0,26 & 0,17 & 0,43 & 21,53 & 90,7 & 8,88 & 2,3 & 0,58 & 2,28 & 159 \\
\hline 6 & 8,48 & 0,32 & 0,18 & 0,49 & 15,33 & 353,46 & 8,06 & 2,38 & 0,47 & 2,53 & 145 \\
\hline 7 & 5,1 & 0,51 & 0,25 & 0,76 & 22,06 & 41,86 & 6,99 & 2,56 & 0,55 & 2,28 & 145 \\
\hline 8 & 4,7 & 0,37 & 0,2 & 0,58 & 17,06 & 72,46 & 9,47 & 2,35 & 0,53 & 2,08 & 113 \\
\hline 9 & 3,9 & 0,29 & 0,21 & 0,5 & 35,46 & 40,69 & 6,04 & 2,21 & 0,75 & 2,75 & 225 \\
\hline 10 & 5,1 & 0,49 & 0,53 & 1,02 & 23,9 & 136,23 & 7,92 & 2,49 & 0,62 & 2,35 & 199 \\
\hline 11 & 4,29 & 0,33 & 0,19 & 0,53 & 18,13 & 56,78 & 9,23 & 2,49 & 0,52 & 2,4 & 136 \\
\hline
\end{tabular}




\begin{tabular}{|c|c|c|c|c|c|c|c|c|c|c|c|}
12 & 5,06 & 0,37 & 0,19 & 0,57 & 20,5 & 32,78 & 6,45 & 2,14 & 0,63 & 1,69 & 166 \\
\hline 13 & 5,26 & 0,32 & 0,25 & 0,57 & 20,7 & 122,74 & 5,62 & 1,61 & 0,59 & 2,16 & 144 \\
\hline 14 & 5,21 & 0,44 & 0,23 & 0,67 & 26,7 & 94,04 & 6,2 & 1,77 & 0,5 & 2,02 & 138 \\
\hline 15 & 4,96 & 0,43 & 0,19 & 0,62 & 16,83 & 102,39 & 6,91 & 2,13 & 0,44 & 1,78 & 141 \\
\hline
\end{tabular}

Tablo 2. Demir noksanlı̆̆ şartlarında fasulye çeşitlerinde belirlenen bazı özelliklere ilişkin oransal değerler $(45 \mu \mathrm{M}$ yeterli demir dozuna göre)

\begin{tabular}{|c|c|l|c|c|}
\hline $\begin{array}{c}\text { Fasulye } \\
\text { çșit no }\end{array}$ & $\begin{array}{c}\text { Oransal } \\
\text { kuru } \\
\text { madde, } \\
\text { \% }\end{array}$ & $\begin{array}{c}\text { Oransal } \\
\text { klorofil-a } \\
\text { kapsamI, } \\
\text { \% }\end{array}$ & $\begin{array}{c}\text { Oransal } \\
\text { klorofil-b } \\
\text { kapsamı, } \\
\text { \% }\end{array}$ & $\begin{array}{c}\text { Oransal } \\
\text { toplam } \\
\text { klorofil } \\
\text { kapsamI, } \\
\text { \% }\end{array}$ \\
\hline 1 & 96,80 & 27,93 & 37,60 & 31,31 \\
\hline 2 & 89,61 & 42,88 & 39,32 & 40,25 \\
\hline 3 & 112,54 & 54,04 & 56,10 & 55,39 \\
\hline 4 & 106,30 & 49,92 & 42,02 & 46,55 \\
\hline 5 & 110,73 & 27,68 & 31,19 & 29,20 \\
\hline 6 & 107,79 & 43,49 & 45,46 & 46,57 \\
\hline 7 & 92,45 & 60,11 & 42,47 & 52,61 \\
\hline 8 & 78,22 & 32,75 & 29,65 & 35,54 \\
\hline 9 & 88,54 & 34,86 & 49,50 & 39,94 \\
\hline 10 & 124,47 & 74,39 & 119,40 & 97,25 \\
\hline 11 & 92,11 & 26,06 & 33,48 & 28,41 \\
\hline 12 & 108,45 & 43,99 & 40,84 & 42,89 \\
\hline 13 & 94,81 & 43,31 & 55,37 & 47,43 \\
\hline 14 & 96,82 & 54,04 & 49,68 & 52,53 \\
\hline 15 & 93,94 & 46,65 & 39,21 & 43,56 \\
\hline
\end{tabular}

Tablo 3. Demir noksanlığı şartlarında fasulye çeşitlerinde belirlenen bazı özelliklere ilişkin oransal değerler $(100 \mu \mathrm{M}$ yeterli demir dozuna göre)

\begin{tabular}{|c|c|c|c|c|c|}
\hline $\begin{array}{c}\text { Fasulye } \\
\text { ceșit no }\end{array}$ & $\begin{array}{c}\text { Oransal } \\
\text { kuru } \\
\text { madde, } \\
\text { \% }\end{array}$ & $\begin{array}{c}\text { Oransal } \\
\text { klorofil-a } \\
\text { kapsamı, } \\
\text { \% }\end{array}$ & $\begin{array}{c}\text { Oransal } \\
\text { klorofil-b } \\
\text { kapsamı, } \\
\text { \% }\end{array}$ & $\begin{array}{c}\text { Oransal } \\
\text { toplam } \\
\text { klorofil } \\
\text { kapsamı, } \\
\text { \% }\end{array}$ & $\begin{array}{c}\text { Oransal } \\
\text { aktif } \\
\text { demir } \\
\text { kapsamı, } \\
\text { \% }\end{array}$ \\
\hline 1 & 97,34 & 34,36 & 46,19 & 38,51 & 101,67 \\
\hline 2 & 85,96 & 42,3 & 51,27 & 44,56 & 95,87 \\
\hline 3 & 125,27 & 47,81 & 58,48 & 51,62 & 71,97 \\
\hline 4 & 132,35 & 53,99 & 44,47 & 50,29 & 89,46 \\
\hline 5 & 99,26 & 38,42 & 40,89 & 39,17 & 90,58 \\
\hline 6 & 103,11 & 42,86 & 41,57 & 42,43 & 77,2 \\
\hline 7 & 71,23 & 52,99 & 45,78 & 50,34 & 44,32 \\
\hline 8 & 41,96 & 48,8 & 52,42 & 54,12 & 68,61 \\
\hline 9 & 100,35 & 38,3 & 56,5 & 44,53 & 97,47 \\
\hline 10 & 90,55 & 65,68 & 133,73 & 89,23 & 67,82 \\
\hline 11 & 94,83 & 31,98 & 40 & 34,53 & 94,67 \\
\hline 12 & 85,51 & 45,96 & 47,58 & 46,39 & 104,05 \\
\hline 13 & 111 & 39,99 & 54,91 & 45,32 & 88,62 \\
\hline 14 & 111,79 & 58,62 & 55,29 & 54,96 & 108,74 \\
\hline 15 & 98,71 & 40,75 & 38,36 & 42,91 & 83,4 \\
\hline
\end{tabular}

Tablo 1 incelendiğinde, demir noksanlığ yüksek kuru madde miktarı 4 nolu çeşitte, en düşük kuru madde miktarı ise 9 nolu çeşitte görülmüştür. Yaprakta klorofil-a kapsamı en yüksek 7 nolu çeşitte, en düşük 1 nolu çeşitte; yaprakta klorofil-b kapsamı en yüksek 10 nolu çeşitte, en düşük 5 nolu çeşitte; yaprakta toplam klorofil kapsamı en yüksek 10 nolu çeşitte en düşük 1 ve 5 nolu çeşitlerde; yaprakta aktif demir kapsamı en yüksek 9 nolu çeşitte, en düşük 2 nolu çeşitte; kök katyon değişim kapasitesi en yüksek 8 nolu çeşitte, en düşük 13 nolu çeşitte; yaprakta ferrik redüktaz aktivitesi en yüksek 6 nolu çeşitte, en düşük 2 nolu çeşitte elde edilmiştir. Aynı şekilde, demir noksanlığı şartlarında bitkide azot kapsamı en yüksek 3 nolu çeşitte en düşük 13 nolu çeşitte; fosfor kapsamı en yüksek 3 nolu çeşitte, en düşük 15 nolu çeşitte; potasyum kapsamı en yüksek 2 nolu çeşitte, en düşük 12 nolu çeşitte; toplam demir kapsamı en yüksek 9 nolu çeşitte, en düşük 8 nolu çeşitte görülmüştür.

$45 \mu \mathrm{M}$ demir çözeltisi verilerek yetiştirilen demir beslenmesi yeterli bitkilere göre demir noksanlığ1 şartlarında yaprakta oransal klorofil-a, klorofil-b, toplam klorofil en yüksek 10 nolu çeşitte elde edilmiştir. Oransal klorofil-a ve toplam klorofil en düşük 11 nolu çeşitte; oransal klorofil-b ise en düşük 8 nolu çeşitte tespit edilmiştir. Oransal kuru madde miktarı ise en yüksek 4 nolu çeşitte; en düşük 8 nolu çeşitte tespit edilmiştir. Aynı şekilde, $100 \mu \mathrm{M}$ demir çözeltisi verilerek yetiştirilen demir beslenmesi yeterli bitkilere göre demir noksanlığı şartlarında oransal kuru madde miktarı, oransal aktif demir, oransal klorofil-a, oransal klorofil-b, oransal toplam klorofil kapsamları en yüksek 10 nolu çeşitte görülmüştür. Demir noksanlığı şartlarında en düşük oransal kuru madde miktarı 8 nolu çeşitte; oransal aktif demir 7 nolu çeşitte; oransal klorofil-a 11 nolu çeşitte; oransal klorofill-b ise 15 nolu çeşitte; oransal toplam klorofil 11 nolu çeşitte tespit edilmiştir.

Demir noksanlığı şartlarında belirlenen özellikler bakımından 10 nolu çeşidin tamamen farklı bir grupta yer aldığ $1,1,5,2,11,6,3$ ve 9 nolu çeşilerin ikinci grupta; 4, 12, 15, 13, 14, 7 ve 8 nolu çeşitlerin ise üçüncü grupta yer aldığı görülmüştür (Şekil 1).

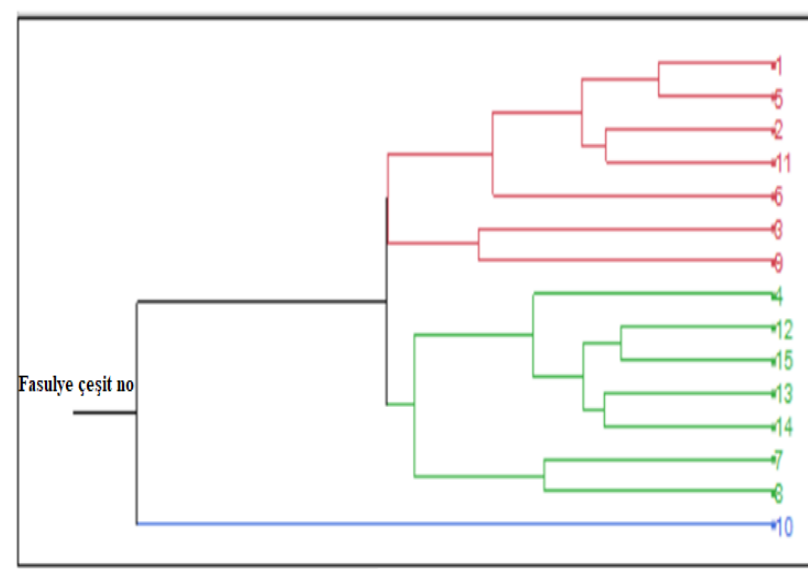

Sekil 1. Demir noksanlığı şartlarında fasulye ceșitlerinin demir beslenme indeksleri ve diğer özelliklerine göre gruplandırılması

Fasulye çeşitlerin yakınlık uzaklık değerleri Tablo 4'te verilmiştir.

Tablo 4. Demir noksanlığı şartlarında yetiştirilen fasulye çeşitlerinin demir beslenme indeks değerleri dikkate alınarak belirlenen yakınlıkuzaklık değerleri

\begin{tabular}{|c|c|c|c|}
\hline Grup sayıları & $\begin{array}{c}\text { Grup içi yakınlık } \\
\text { değeri }\end{array}$ & \multicolumn{2}{c|}{ Grup Elemanları } \\
\hline 14 & 1,701 & 1 & 5 \\
\hline 13 & 2,256 & 12 & 15 \\
\hline 12 & 2,472 & 2 & 11 \\
\hline 11 & 2,508 & 13 & 14 \\
\hline 10 & 2,821 & 12 & 13 \\
\hline 9 & 2,831 & 1 & 2 \\
\hline 8 & 3,384 & 7 & 8 \\
\hline
\end{tabular}




\begin{tabular}{|c|c|c|c|}
\hline 7 & 3,553 & 4 & 12 \\
\hline 6 & 4,155 & 1 & 6 \\
\hline 5 & 4,363 & 3 & 9 \\
\hline 4 & 5,329 & 4 & 7 \\
\hline 3 & 5,719 & 1 & 3 \\
\hline 2 & 5,740 & 1 & 4 \\
\hline 1 & 9,445 & 1 & 10 \\
\hline
\end{tabular}

Tablo 4'ün incelenmesinden de görüleceği gibi demir noksanlığı şartlarında 1 ve 5 nolu çeşitlerin birbirine en yakın; 1 ve 10 nolu çeşitlerin ise birbirine en uzak çeşitler olduğu tespit edilmiştir.

$\mathrm{Fe}$ noksanlığı şartlarında incelenen bazı özelliklere ilişkin ortalama değerler dikkate alınarak, özelliklerin çeşitlere göre sınıflandırılması ve çeşitlerin de incelenen özelliklere göre değişimi Şekil 2'de verilmiştir.

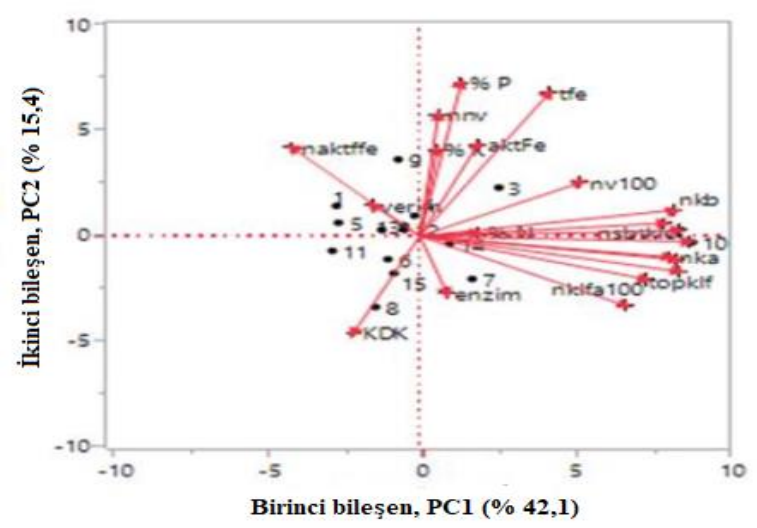

Şekil 2. Demir noksanlığı şartlarında çeşitlerin gruplandırılması ve bu çeşitlerin en iyi demir beslenme özellikleri

Biplot Yöntemi ile yapılan analizde PC1 (1. ana bileşen) \% 42,1, PC2 (2. ana bileşen) \% 15,9, PC1 ve PC2'nin toplamı ise varyasyonun \% 58'ini oluşturmuştur. Şekil 2'de görüldüğü gibi, çeşitlere göre incelenen özellikler ve çeşitlerin dağılımları farklılık göstermiştir. Demir noksanlığı şartlarında yaprakta belirlenen ferrik redüktaz aktivitesi, oransal klorofil-a (100 $\mu \mathrm{M}$ Fe uygulamasında klorofil-a kapsamına göre), toplam klorofil, oransal klorofil-a (45 $\mu \mathrm{M}$ Fe uygulamasinda klorofil-a kapsamina göre) ve oransal toplam klorofil $(100 \mu \mathrm{M} \mathrm{Fe}$ uygulamasında toplam klorofil kapsamına göre) aynı grupta yer alırken, demir noksanlığı şartlarında bitkide belirlenen \% N kapsamı, oransal toplam klorofil (45 $\mu \mathrm{M}$ Fe uygulamasinda toplam klorofil kapsamına göre), oransal klorofil-b (45 $\mu \mathrm{M}$ Fe uygulamasinda klorofil-b kapsamına göre), oransal kuru madde (100 $\mu \mathrm{M} \mathrm{Fe}$ uygulamasında elde edilen kuru maddeye göre), yaprakta aktif $\mathrm{Fe}$, toplam $\mathrm{Fe}, \% \mathrm{~K}, \% \mathrm{P}$ kapsamları ve oransal kuru madde miktarı (45 $\mu \mathrm{M}$ Fe uygulamasında elde edilen kuru madde miktarına göre) gibi özellikler de kendi içerisinde aynı grupta yer almışlardır. Demir noksanlığı şartlarında belirlenen oransal aktif demir (45 $\mu \mathrm{M}$ Fe uygulamasında yaprakta aktif demir kapsamına göre) ve kuru madde miktarı aynı grupta toplanırken; kök katyon değişim kapasitesi (KKDK) farklı bir grupta toplanmıştır.

Araştırmada incelenen 1, 4, 5, 9, 12 ve 13 numaralı çeşitlerin demir noksanlığı şartlarında oransal aktif $\mathrm{Fe}$

(45 $\mu \mathrm{M}$ Fe uygulamasında yaprakta aktif demir kapsamına göre) ve kuru madde miktarları bakımından iyi çeşitler oldukları belirlenmiştir. Aynı şekilde, demir noksanlığı şartlarında $6,8,11$ ve 15 numaralı çeşitler ise KKDK yönünden iyi çeşitler oldukları belirlenmiştir. Demir noksanlığı şartlarında 7,10 ve 14 numaralı çeşitlerin yaprakta ferrik redüktaz aktivitesi, oransal klorofil-a (100 $\mu \mathrm{M}$ Fe uygulamasina göre), toplam klorofil, oransal klorofil-a (45 $\mu \mathrm{M}$ Fe uygulamasinda klorofil-a kapsamına göre) ve oransal toplam klorofil (100 $\mu \mathrm{M} \mathrm{Fe}$ uygulamasına göre) yönünden iyi çeșitler oldukları belirlenmiştir. Demir noksanlığı şartlarında 3 numaralı çeşidin ise incelenen diğer özellikler yönünden bitkide \% N kapsamı, yaprakta oransal toplam klorofil (45 $\mu \mathrm{M}$ Fe uygulamasında toplam klorofil kapsamına göre), oransal klorofil-b, (45 $\mu \mathrm{M}$ Fe uygulamasında klorofil-b kapsamına göre), oransal kuru madde miktarı (100 $\mu \mathrm{M} \mathrm{Fe} \mathrm{uygulamasina} \mathrm{göre),} \mathrm{yaprakta} \mathrm{aktif} \mathrm{Fe,}$ toplam $\mathrm{Fe}, \% \mathrm{~K}, \%$ P kapsamları ve oransal kuru madde miktarının (45 $\mu \mathrm{M}$ Fe uygulamasında elde edilen kuru madde miktarına göre) iyi olduğu belirlenmiştir.

İkinci grubun çeşitleri arasında klorofil-a kapsamı yönünden en yüksek çeşit 3 nolu çeşit; en düşük çeşit ise 1 nolu çeşit bulunmuştur. Üçüncü grubun çeşitleri arasında en yüksek klorofil-a kapsamı 7 nolu çeşitte; en düşük klorofil-a kapsamı ise 13 nolu çeşitte bulunmuştur. Toplam klorofil kapsamı yönünden ise ikinci grubun en yüksek çeşidi 3 nolu çeşit, en düşük çeşidi 1 ve 5 nolu çeşitler olmuştur. Üçüncü grubun çeşitleri arasında toplam klorofil kapsamı yönünden en yüksek çeşit 7 nolu çeşit, en düşük çeşit ise 4 nolu çeşit bulunmuştur. Aktif demir kapsamı yönünden ikinci grubun en yüksek çeşidi 9 nolu çeşit, üçüncü grubun en yüksek çeşidi ise 14 nolu çeşit bulunmuştur. Bitkilerin demir beslenme durumlarının belirlenmesinde toplam demirin iyi bir ölçü olmadığı belirtilmiştir [21]. Bu nedenle klorofil oluşumunda sorumlu olan aktif demir, demir noksanlığının tespitinde daha kullanılabilir bir ölçüt olduğu belirtilmiştir [22].

Yaprakta ferrik redüktaz aktivitesi yönünden ikinci grubun en yüksek çeşidi 6 nolu çeşit, üçüncü grubun en yüksek çeşidi ise 13 nolu çeşit bulunmuştur. Oransal toplam klorofil yönünden ikinci grupta en yüksek değeri 3 nolu çeşit, üçüncü grupta ise 14 nolu çeşit sağlamıştır.

Demir noksanlığ şartlarında klorofil-a kapsamı birbirine en uzak 1 ve 10 nolu çeşitlerde sırası ile $0,25 \mathrm{mg} / \mathrm{g}$ taze madde (TM) ve $0,49 \mathrm{mg} / \mathrm{g}$ TM bulunmuş; klorofil-b kapsamı sirasiyla $0,18 \mathrm{mg} / \mathrm{g}$ TM ve $0.53 \mathrm{mg} / \mathrm{g} \mathrm{TM}$; toplam klorofil kapsamı sirasiyla $0,43 \mathrm{mg} / \mathrm{g}$ TM ve 1,02 mg/g TM; aktif demir kapsamı sirasıyla 20,73 ppm ve 23,90 ppm bulunmuştur. Demir noksanlığına tolerans indeks değerleri (45 $\mu \mathrm{M}$ demir çözeltisiyle beslenen bitkilere göre) klorofil-a yönünden birbirine en uzak 1 ve 10 nolu çeşitlerde sırasıyla \% 27,93 ve \% 74,39; klorofilb yönünden sırası ile \% 37,60 ve \% 119,4; toplam klorofil yönünden sirasıly $\% \quad 131,31$ ve $\% \quad 97,2$ bulunmuştur. Buna göre incelenen özellikler bakımından demir noksanlığ şartlarında 10 nolu çeşit en uygun çeşit olarak önerilebilir. Ayrıca birbirine en uzak 1 ve 10 nolu çeşitlerde yaprakta ferrik redüktaz aktivitesi demir 
noksanlığı şartlarında sırasıyla 27,94 $\mu \mathrm{mol} / \mathrm{saat} / \mathrm{g}$ TM ve $136,23 \mu \mathrm{mol} / \mathrm{saat} / \mathrm{g}$ TM bulunmuştur. Slatni ve ark. [23] demir noksanlığına dayanıklı Flamingo fasulye çeşidinde ferrik redüktaz aktivitesinin hassas çeşit olan Coco Blanc'a göre daha yüksek olduğunu bildirmişlerdir.

Demirli gübrelemeye 1 ve 10 nolu çeşitler kuru madde miktarı bakımından respons vermemişlerdir. Fakat klorofil-a, klorofil-b ve toplam klorofil kapsamı bakımından 1 nolu çeşit demirli gübrelemeye respons göstererek demirli gübreleme sonucu klorofil-a, klorofilb ve toplam klorofil 1 nolu çeşitte artış göstermiştir. Buna karşın 10 nolu çeşitte demirli gübrelemenin klorofil-a, klorofil-b ve toplam klorofil kapsamına etkisi önemsiz bulunmuştur. Slatni ve ark. [23], demir noksanlığına toleranslı Flamingo fasulye çeşidinin demir noksanlığına hassas Coco Blanc fasulye çeşidine göre demir noksanlığı şartlarında klorofil kapsamının daha yüksek olduğunu bildirmişlerdir. Araştırıcılar demir noksanlığına toleranslı Flamingo fasulye çeşidinde demir noksanlığı şartlarında klorofil kapsamının demirce yeterli şartlara göre \% 34 azaldığını, demir noksanlığına hassas Coco Blanc fasulye çeşidinde ise klorofil kapsamının demirce yeterli şartlara göre \% 76 azaldığını bildirmişlerdir. Diğer bir ifadeyle, araştırıcılar Coco Blanc fasulye çeşidinde klorofil kapsamının demirli gübrelemenin etkisiyle Flamingo fasulye çeşidine göre daha fazla arttığını bildirmişlerdir. Araştırıcılar Flamingo fasulye çeşidinde demir noksanlığı şartlarında toplam biokütlenin \% 27 oranında azaldığını, Coco Blanc fasulye çeşidinde ise \% 50 oranında azaldığını da bildirmişlerdir. Klorofil ve karotenoidin biyosentezinde demirin gerekliliği belirtilmiştir [24, 25, 26]. Bitkiye demirin yarayışlılığının ortaya konulmasında klorofil biyosentezinin iyi bir indikatör olduğu, demirin yeterince alınamadığı durumlarda bitkilerin yapraklarında klorofil sentezinin inhibe edildiği belirtilmiştir [27]. Marschner [28], demir her ne kadar klorofil molekülünün yapısına girmiyorsa da klorofilin bitkideki sentezinde önemli rol oynadığını bildirmiştir. Gelişme parametreleri ve yaprak klorofil kapsamının çeşit ve demirin alınabilirliğine bağlı olarak farklı etkilendi de bildirilmiştir [29].

\section{SONUÇ}

Fasulye yetiştiriciliğinde demir noksanlığının önlenmesinde genetik kontrolün, diğer bir ifadeyle çeşit seçiminin önemli olduğu sonucuna varılmıştır. Demir noksanlığı şartlarında fasulye çeşitlerinin demir beslenme kabiliyetlerinin farklı olduğu görülmüştür.

Demir beslenme kabiliyetleri yönünden demir noksanlığ1 şartlarında 10 nolu çeşit tamamen farklı grupta yer alırken, 1, 5, 2, 11, 6, 3 ve 9 nolu çeşitler farklı grupta (2.Grup); 4, 12, 15, 13, 14, 7 ve 8 nolu çeşitler ise başka grupta (3. Grup) kümelenmiştir.

Buna göre incelenen özellikler bakımından demir noksanlığı şartlarında 10 nolu çeşit (Eskfbud-7,bodur) en uygun çeşit bulunmuştur. Demirli gübrelemeye 1 ve 10 nolu çeşitler verim bakımından cevap vermemişlerdir. Fakat klorofil-a ve klorofil-b ve toplam klorofil kapsamı bakımından 1 nolu çeşit demirli gübrelemeye cevap göstererek demirli gübreleme sonucu 1 nolu çeşitte klorofil-a, klorofil-b ve toplam klorofil artış göstermiş; buna karşın 10 nolu çeşitte demirli gübrelemenin klorofil-a, klorofil-b ve toplam klorofil kapsamına etkisi önemsiz bulunmuştur. İncelenen özellikler bakımından en iyi çeşidin 10 nolu çeşit olmakla birlikte, 3 nolu (Eskfbud-2, sırık), ve 7 nolu (Eskfbud-11, sırık) çeşitlerin de demir noksanlığ 1 şartlarında iyi çeşitler olduğu tespit edilmiştir.

\section{KAYNAKLAR}

[1] Tang CR, Obson AD. Lupinus species differ in their requirements for iron. Plant Soil. 1993;157: 11-18.

[2] Moreau S, Meyer JM, Puppo A. Uptake of iron by symbiosomes and bacteroids from soybean nodules. FEBS Letters. 1995;361: 225-228.

[3] Hardarson G. Use of nuclear techniques in studies of soil-plant relationships. International Atomic Energy Agency, Vienna; 1990.

[4] O'Hara GW, Dilworth MJ, Boonkerd N, Parkpion P. Iron deficiency specifically limits nodule devolopment in peanut inoculated with Bradyrhizobium sp. New Phytol. 1988;108:51-57.

[5] Krouma A, Drevon J, Abdelly C. Genotypic varition of $\mathrm{N}_{2}$-fixing common bean (Phaseolus vulgaris L.) in response to iron deficiency. Plant Physiol. 2006;163(11):1094-1100.

[6] Eyüpoğlu F, Kurucu N. Plant available trace iron, zinc, manganese and copper in Turkey soils, (ed. J. Ryan), In: Accomplishments and Future Challenges in Dryland Soil Fertility Research in the Mediterranean Area, ICARDA Book, 1997. p.191196.

[7] Özgümüş A. Bitkilerde demir klorozu. Uludağ Üniversitesi Ziraat Fakültesi Dergisi. 1987;6:117128.

[8] Römheld V. Different strategies for iron acquisition in higher plants. Plant Physiol. 1987;70:231:234.

[9] Bavaresco L, Fregoni M, Fraschini P. Investigations on iron uptake and reduction by excised roots of different grapevine rootstocks and a Vitis vinifera cultivar. Plant Soil. 1991;130:109. 113.

[10] Rombola AD, Bruggemann W, Lopez-Millan, AF, Tagliavini M, Abadia J, Marangoni B, Moog PR. Biochemical responses to iron deficiency in kiwifruit (Actinidia deliciosa). Tree Physiol. 2002;22:869-875.

[11] Krouma A, Abdelly C. Importance of iron use efficiency in common bean (Phaseolus vulgaris L.) for iron chlorosis resistance. J Plant Nutr. And Soil Sci. 2003;4:525-528.

[12] Chaney RL, Brown JC, Tiffin LO. Obligatory reduction of ferric chelates in iron uptake by soybeans. Plant Physiol. 1972;50:734-739.

[13] Römheld V, Marschner H. Evidence for a specific uptake system for iron phytosiderophores in roots of grasses. Plant Physiol. 1986;80:175-180. 
[14] Marschner H, Römheld V, Kissel M. Different strategies in higher plants in mobilization and uptake of iron. J Plant Nutr. 1986;9:695-713.

[15] Hewitt EJ. Sand and water culture methods used in the study of plant nutrition; 1966.

[16] Kacar B, İnal A. Bitki Analizleri, 1. Basım. Nobel Yayınları, Ankara; 2008.

[17] Ojeda M, Schaffer B, Davies FS. Root and leaf ferric chelate reductase activity in pond apple and soursop. J Plant Nutr. 2004;27:1381-1393.

[18] Takkar PN, Kaur NP. HCI method for $\mathrm{Fe}^{+2}$ estimation to resolve iron clorosis in plant. J Plant Nutr. 1984;7(1-5):81-90.

[19] Arnon D. Copper enzymes in isolated chloroplast polyphenoloxidase in beta vulgaris. Plant Physiol. 1949;24:1-15.

[20] Withan FH, Blayedes DF, Devlin RM. Experiments in Plant Physiology. Van Nostrand Reinhold Co., New York. 1971. p.55-58.

[21] Chen Y, Barak P. Iron nutrition of plants in calcerous soils. Adv. Agron. 1982;35:217-240.

[22] Lang HJ, Reed DW. Comparison of $\mathrm{HCl}$ extraction versus total iron analysis for ron tissue analysis for iron tissue analysis. J Plant Nutr. 1987;10 (7):107116.

[23] Slatni T, Krouma A, Gouia H, Abdelly C. Importance of ferric chelate reductase activity and acidification capacity in root nodules of $\mathrm{N}_{2}$-fixing common bean (Phaseolus vulgaris L.) subjected to iron deficiency. Symbiosis. 2009;47: 35-42.

[24] Morales F, Abadia A, Abadia J. Characterization of the xanthophyll cycle and other photosynthetic pigment changes induced by iron deficiency in sugar beet (Beta vulgaris L.). Plant Physiol. 1990;94:607-613.

[25] Terry N, Zayed AM. Physiology and biochemistry of leaves under iron deficiency. In: Iron nutrition in soils and plants, Abadia, J., ed. Kluwer Academic Publishers, Dordrecht, The Netherlands. 1995. p. 283-294.

[26] Thoiron S, Pascal N, Briat JF. Impact of iron deficiency and iron re-supply during the early stages of vegetative development in maize (Zea mays L.). Plant Cell Environ. 1997;20:1051-1060.

[27] Lopez-Millan AF, Morales F, Abadia A, Abadia J. Changes induced by Fe deficiency and Fe resupply in the organic and metabolism of sugar beet (Beta vulgaris) leaves. Physiol. Plant. 2001;112:31-38.

[28] Marschner H. Mineral nutrition of higher plants. Institute of Plant Nutrition University of Hohenheim Federal Republic of Germany. Academic Press; 2002.

[29] Krouma A, Slatni T, Abdelly C. Differential tolerance to lime-induced chlorosis of $\mathrm{N}_{2}$-fixing common bean (Phaseolus vulgaris L.) Symbiosis. 2008;46:137-143. 